\title{
横浜市大岡川・中村川下流域における運河の発展と衰退 \\ Development and Decline of Canals in the Ooka and Nakamura basin in Yokohama City
}

田邊 徳子* 古谷 勝則*

\author{
Nolico TANABE Katsunori FURUYA
}

\begin{abstract}
This study focuses on the functions of rivers serving as canals. The Ooka and Nakamura basin in Yokohama City was designated as a study subject. The history of development and decline of canals, which had been affected by changes in the roles of canals, had been clarified. Bibliographical research and spatial analysis with a graphic plan and topographical maps were conducted for the investigation. The subject area was reclaimed land which was completed 350 years ago, and some changes were triggered by the opening of Port of Yokohama. Furthermore, multiple canals were built in the middle of the Meiji Period in order to improve convenience of transportation and to protect foreign settlements. At that point, canals were the foundation of everyday life. However, demand for canals started diminishing towards the middle of the Showa Period due to the new establishment of railways and motorways, and canals were started to be filled in or converted to culverts towards the end of the Showa. The remaining area is now utilized as a subway, green passage or parks. Therefore, it is concluded that the canals are important components of the current city landscape with the history of development and decline.
\end{abstract}

Keywords: Yokohama city, canal, Landscape, development, decline, transition キーワード：横浜市, 運河, 風景, 発展, 衰退, 変遷

\section{1. はじめに}

自然の恵みである水を主役とした河川空間・水空間は都市景観 を構成する重要な要素となる。都市化される前の農村では, 河川 から引き込んだ水路が人々の生活の軸として重要な空間になって いた。また河川は，物流などの拠点として，人々の生活に深くか かわっていた。それ故，河川は人々の活動の圧力を長きにわたっ て強く受け，特に高度経済成長期には都市域を中心として河川空 間・水空間は大きく変化することとなった。その一連の経過の中 で，河川とともに育まれてきた地域の風土や文化も損なわれてい き，人々は地域の中で日常感じることのできた地域における河川 の魅力から離れていってしまった。河川の魅力を取り戻すために も, 河川の発展や消失過程, その痕跡が果た寸現在の新たな機能 に着目することが必要である。

都市部における河川や運河の発展や消失過程を扱った研究とし ては，白藤ら（2009）1)は，東京都を対象に古地図と現在の場所 を比較し，文献調査や現地調査を行った。このことから，暗渠化 された河川が，現在の風景に及ぼしている影響をプラス面とマイ ナス面の両方から明らかにした。都市の近代化が河川に及ぼした 影響に関する研究としては，高橋ら（1986）2)は，23 区の河川を 対象として地形図を用いて計測を行い，時代ごとに利用形態を分 類した。その結果, 河川の幅員と道路や住宅への転用に関して, 区ごとに特色が認められたことを明らかにした。小川（2011）3 は，東京都淽谷川を対象に江戸時代以降の地図や絵写真を用いて 空間の復元考察を行った。このことから，水路が風景に果たした 役割の変化を利用や空間構造などの観点から明らかにし, 暗渠を, 都市の特徵を色濃く残す貴重な存在と結論付けた。岡ら（2008） 4)は，横浜市大岡川を対象に横浜港開港から現代まで，地形図を もとに分析を行った。埋立や農村の宅地化について, 地形図から, 水路, 農地, 人の住みつき方の変遷について示した。吉田ら (2008) 5)は，日本で初めて鉄道が敷かれた新橋と野毛地区を対象とし， 舟運を主として発展していた両都市に鉄道開通が与えた影響につ
いて明らかにした。加えて，土地宝典を用いた地価の比較や戦後 発展した街の業種分布を戦前·戦後に分けて比較した。その結果, 新橋においては開通後直ちに, 野毛地区においては戦後, 駅前を 中心として発展が始まり, 発展の開始時期の相違が現在の両都市 の性格の違いとなっていると結論付けた。この研究では, 横浜で は鉄道開通後も問屋街として栄えた運河の文化が残っていたこと を指摘していた。

以上より，都心部における河川は近代の都市化に応じて埋立て や暗渠化が進み，市街地や道路へと転用されていることが明らか となっている。特に横浜においては, 横浜港の開港による宅地化 や日本初の鉄道敷設などを契機として都市化が進んだ結果，埋立 や暗渠化が進んでいることがわかる。したがって, 横浜市の現存 する河川や，埋立・暗渠化された河川の痕跡そのものにも，当時 の都市の特徵を色濃く残寸貴重な存在として, 価值を見出すこと が可能であると考えられる。しかし, 現在の研究では河川空間周 辺を対象とした土地利用形態の変化に関する研究にとどまってお り, 河川そのものの発展と衰退, その痕跡が果たす現在の新たな 機能に着目した研究は少ない。そこで本研究では，近代における 都市化の先駆けとなった横浜市の大岡川・中村川下流域を対象と し，「運河の発展と衰退の経緯」と「現在の都市施設の創造」との 関係性を明らかにすることを目的とした。

なお本研究では, 対象河川の主な利用形態であった運河として の機能に着目し，対象河川を運河と呼ぶこととした。

\section{2. 研究の方法}

\section{（1）対象地の選定}

本研究の対象地としては(1)入江が埋立てられ完成した人工の土 地であること(2)横浜港開港以降, 開削によって完成した運河が数 多く存在したこと, (3)開削された運河の大半が現在, 埋立や干拓, 暗渠化により姿を消していること, (4)その跡地に, 他の交通網や 緑地・緑道などの都市施設が整備されていること等の選定理由か

*千葉大学大学院園芸学研究科 
ら，横浜市南区と中区にまたがる大岡川と中村川・堀川下流域を 対象地とした（図－1）60-10）。横浜市道路局によると，大岡川・ 中村川・堀川はいずれも県知事管理の二級河川であり，大岡川の 全長は計 $14,040 \mathrm{~m}$, 中村川の全長は $3,000 \mathrm{~m}$, 堀川の全長は $900 \mathrm{~m}$ である 11)。

南区の面積は, 横浜市統計ポータルサイトによると $12.63 \mathrm{~km}^{2}$, 中区の面積は $20.81 \mathrm{~km}^{2}$ である。人口・世帯数は, 平成 25 年 7 月 1 日現在，南区は 194,764 人・93,685 世帯，中区は 147,058 人・76,898 世帯である。いずれの区も，1950 年頃から 1970 年 頃までの高度経済成長に呼応し人口増加が顕著となっている ${ }^{12)}$ (南区は，1970 年に港南区と分裂した） 13)。

土地利用に関して，建築局企画部都市計画課によると，南区は 平成 24 年度，区域の $76 \%$ が住宅地域， $4 \%$ が工業地域， $20 \%$ が 商業地域となっている。この值から，横浜市全域における土地利 用と比較し, 商業地域としての利用が高いといえる。これに対し， 中区の土地利用は，区域の $35 \%$ 方住宅地域，29\%が工業地域， $36 \%$ が商業地域であり, 横浜市全域と比較し, 商業地域と工業地 域の割合が高いといえる14)。

\section{(2) 研究の方法}

大岡川・中村川下流域の運河は, 1859 (安政 6) 年の横浜港開 港以降の市街化に伴って開削が進んだ。そこで，対象地における それぞれの運河が，どのような経緯により成立したのかを文献調 査より明らかにする。文献調査には, 横浜市史稿や横浜市史, 中 区史を主に用い，運河の発展と衰退，都市施設を表 - 1 の年表に まとめた。また，当時流れていた運河の位置を古絵罒や航空写真 から判読し，GIS を用いて現在の新しい都市施設を表示した。こ れら情報を比較し，過去の運河の所在地と現在の都市施設の関連 性に関する空間分析を行った（図－4）15)-19)。これら調査結果を もとに，社会的背景により時代を大別し，運河の成立過程や不要 とされた経緯, 運河に求められた機能等に着目し総合考察を行っ た。

\section{3. 横浜港開港以前の様子}

江戸が爛熟した文化に彩られた時期には，横濱村は千鳥鳴く浜 辺に松の間を縫って畑がちらほら見える程度であったという。こ の入江に埋め立てを行ったのは，当時江戸本材木町に居住し，石 材・木材を手広く商売していた吉田勘兵衛良信であった ${ }^{20)}$ 。吉田 勘兵衛は，1656（明暦 2) 年に幕府の許可を受けた後，石川中村 大丸山の土砂を切り崩し，9 年の歳月をかけ，1667（寛文 7）年 に難工事を完成させた。その際に完成した埋立地が，吉田新田で ある。当時の総面積は三十四万八千余坪 (約 115ha), 工事費用

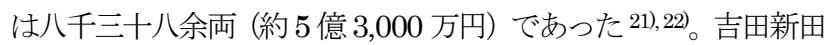
と入江の間は当初，「蛇行はなはだし」23)かった。そこで両護岸に は石垣が築かれ，水を引いた水路や橋梁，灰汁水吐出門などが設 けられた。これが大岡川と中村川の始まりである。しかし，これ まで海であったところを土砂で埋め立てた当初の田畑では直に良 好な作徳を望むことは困難であった。そのため, 新田完成後, 代々 の継承者が多くの小作人を率いて土地をならし，共存共栄のため に更なる埋立・開墾の事業に努めた ${ }^{24)}$ 。吉田新田の埋立開墾を先 駆けとして，1796（寛政 8）年には現在の中華街周辺において, 横浜新田の埋め立て開墾が横浜村民によって行われ 25), 1853 (嘉 永 6）年には, 現在の相生・住吉周辺に太田屋新田の埋め立て開 墾が，太田屋徳九郎によって行われた ${ }^{26)}$ この時代の運河は，農 業用水としての利用が中心であったと推測される。

\section{4. 横浜港開港後と居留地保護}

\section{（1）横浜港開港後 : 市街地の拡大}

1853 （嘉永 6）年のペリー来航後，1858（安政5）年 6 月 19

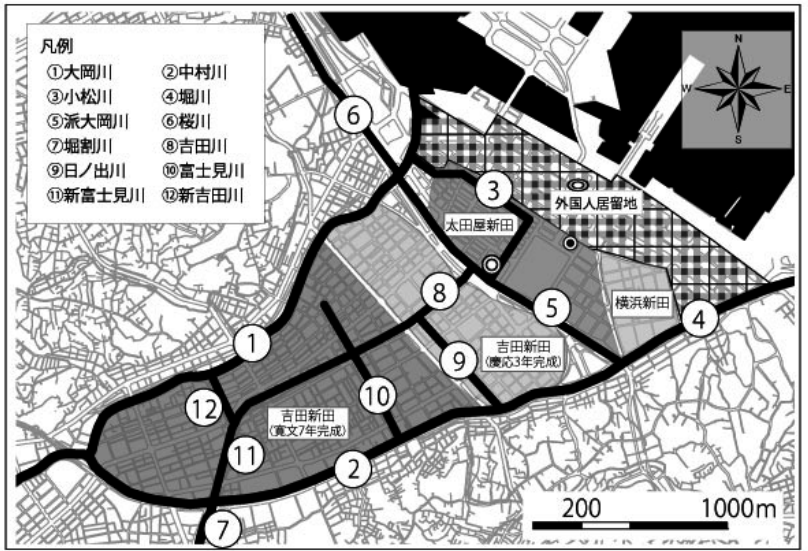

図 - 1 大岡川・中村川（堀川）下流域の概要

日に日米修好通商条約が締結され，1859（安政 6) 年 6 月 2 日に 横浜港が開港した。渡来の外国人数は, 開港元年の 1860 (万延元) 年には在留外国人数は僅加 35 人（英人 18 人，米人 18 人，蘭人 5 人）であったが，開港後は，横浜港周辺に居住していた農家を 掘割の南に移して横濱元町と称し，域内を移住商人及び在留外国 人の商舗・商館の地に充てたため, 在留外国人数は文久・元治・ 慶応年間を経て, 1867 (慶応 3 ) 年には 1,070 人にまで増加した。 その結果, 吉田新田域内総人口は, 開港 8 年後の 1867 (慶応 3 ) 年には 20,810 人, 開港 10 年後の 1869 (明治 2 ） 年には 28,589 人となり，さらに 1872 (明治 5 ) 年には 64,402 人まで増加した 23)。こういった経緯から, 吉田新田において, 明治時代初期頃ま で市街地の拡大が行われた。開港以前の埋立は田畑を広げること が目的であったが，開港以降の埋立は既に田畑となっていた土地 を埋め立て，街を開くことが目的となっていた ${ }^{28)}$ このようにし て, 吉田新田は 1866 (慶応 2 ) 年から明治 40 年代までの四十余 年間に，人口・戸数の増加に伴い市街地が拡大し，人家は新田地 内に充満するに至った。つまり旧新田の地が開港以降この時期に 田畑から街へと変化したといえる ${ }^{29)}$ 。

\section{（2）横浜港開港後 : 浪士による在留外国人の殺傷事件の続発}

横浜港開港後, 日本人浪士による外国人殺傷事件が相次いだ。 1859 (安政6）年7月には本町におけるロシア使節護衛艦隊の見 習士官と水兵の惨殺事件が, 同 10 月には港崎わきにおけるフラン 不領事代理の清国人召使惨殺事件が発生した。清国人召使殺傷事 件の際，犯人を捕らえることができず幕府にとっては重大な失態 となった。さらに, 翌 1860 (万延元) 年 2 月にはオランダ人殺傷 人事件が発生した。外国側から抗議を受けた幕府は，万延元年 4 月から 6 月にかけて，延長 580 間 (1054.4m), 幅 10 間 (18.18m) 30) の掘割を, 現在の山下橋から西の橋あたりまで掘って, 関内 (外 国人居留地) と関外を隔離する工事を行った ${ }^{31)}$ 。この運河が堀川 である。横浜市史稿 ${ }^{32}$ には, 開港後の運河開削の目的として「舟 運の便はもちろん，居留地保護の関係から，危険人物の取締の必 要上形盡されたもの」と記載されている。また，その後 1867 (慶 応 3）年に新たに埋め立てられた吉田新田と, 横浜新田・太田屋 新田間に埋め残された運河が「派大岡川」である。

\section{（3）「町」の新設にともなう下水道の整備}

1871 (明治 4) 年, 横浜市街の測量が実施された。この際, 1864 (元治元) 年発行古絵図 ${ }^{16}$ ) からも存在が確認される運河が，小松 川 (図-1の5）と命名された ${ }^{33)}$ 。しかし小松川は，1872（明治5） 年 9 月, 高島嘉右衛門らの出願によって埋め立てられた ${ }^{34)}$ 。当時 の様子に関して，高島翁言行録 ${ }^{35)}$ には以下のような記述がある。 「明治 4 年の春, 下水溝より発散する臭気鼻を衝き, 実に堪えら れない状況であった関内地域の対策として, 高島が提出した蒝気 ポンプを用いた排水工事案が採用され，実施された。」したがって， 
小松川は舟路としての機能を持たなかった上，悪臭を放つ原因と なっていたため, 早くに下水道としての役目を終え, 埋め立てら れたと考えられる。

\section{5. 横浜の都市化による物資の動きの増大と運河開削の要請} （1）都市化による物資の動きの増大

明治に入り, 人口の増加や横浜の都市化による物資の動きの増 大につれ必要となったのが舟運による方法だった ${ }^{36}$ )。1870 (明治 3 年） 4 月, 神奈川県知事井関盛艮は, 中村川の拡張や根岸堀割 の開削，吉田新田南一ツ目沼地の埋立工事を自費で行う者の募集 をかけた。これに名乗りを上げ，工事実施の許可を得た者が吉田 八代勘兵衛だった。しかし事業は，当初の予想をはるかに上回る 資金を要したため, 八代勘兵衛は資金繰りにあえぐ結末となった。 そのため，政府の救済を経て公業となり，1875（明治 8）年，旧 吉田新田すべての土地が官有地となった 37。堀割川は上流部で中 村川と結ばれ，横浜港と周辺の地域を結ぶ重要な水上交通路とし ての役割を果たすことになった ${ }^{36}$ 。同時に，堀割川開削の際に生 じた土砂を以て吉田新田の沼地を埋め立てることとなった。その 際の工事中に町の区画に沿って開削された運河を吉田川，枝川を 日ノ出川と命名した ${ }^{38)}$ 。したがって, 同時期に開削されたこの二 つの運河に関しては，掘割川開削の際の副産であるといえる。さ らに, 1870 (明治 3) 年に行われた桜木町の埋め立ての際, 川敷 を埋め残し浚渫工事を行い，舟便を通じた ${ }^{39}$ 。この運河が，桜川 (櫻木川とも呼ばれる) であるその後, 桜川は $18 \mathrm{~m}$, 大岡川は $22 \mathrm{~m}$ にそれぞれ川幅が広げられ, 川からの物資の積み降しの便利 のため川の護岸の肩を削って堀川，中村川などと同じように荷揚 場が設けられた。その結果, 舟運上にいちじるしく便利となり, さらに鉄筋造による橋梁がかけられた 40)。富士見川に関しては, 1886（明治 19）年 1 月，伏島近蔵が神奈川県へ開削の申し立て を出願したが費用の面から取りやめとなった後，横浜市により開 削された ${ }^{41)}$ 。

当時の様子に関して, 横濱復興誌 42)には, 以下のような記載が 残されている。「れら艀船を収容するに足る指定繋留場無かりし 為, 空艀船は所々に散在し, 殊に天候不良の際には舷々相摩して 河川内に蝟集し，河川の交通を妨害寸る事女り，特に大岡川及同 支川にてはその甚だしきものあり」。記からも，当時の輸送手段 として舟運は活発であり, 舟路として運河が栄えていたと考えら れる。少し時代は離孔るが，横浜市内運河を利用していた運送艀 船は, 1920 (大正 9 ) 年の横浜市の調查によると 3,098 隻 $(237,951$ トン)，乗用艀船 326 隻であった ${ }^{43)}$ 。

\section{（2）東海道線の開通}

1870 (明治 3$)$ 年 4 月，明治政府の上野景範らが，線路測量を 手始めに京浜間鉄道工事に着手し，1872（明治5）年正月に，ほ ぼ品川・横浜間の鉄道工事が竣工した（官設）。明治 5 年 5 月， 品川・横浜間の仮営業を開始し，10月 13 日より京浜間の鉄道営 業が開始され，1889（明治 22）年 7 月，東京・神戸間が全通し た。この結果, 東京・横浜間における貨物輸送トン数は, 1872 (明 治 5）年から 1886 （明治 19）年にかけて飛躍的に増加した。営 業収入額に占める利益金の比率は, 明治 5 年は $35.6 \%$ であったが, 明治 19 年には $64.9 \%$ にまて増加している ${ }^{44)}$ 。当時の運輸成績に 関して, 旅客人員（人）は1896（明治 29）年を境に減少してい るが，貨物輸送トン数は著增の一途をたどり，明治 40 年代には 明治 5 年のほぼ 485 倍になっていることがわかる。この動向は, 明治 40 年代から大正初期に入っても変わることがなかった 45 。 横浜駅における 1911 (大正元) 年の輸出品の特徴に関して, 茶 · 生系・屑系・木材が多いことが挙げられる。対照的に輸入品の特 徵に関しては, 鉄類・綿類・毛織物・麻などが圧倒的に多いこと が特徴として挙げられる ${ }^{46)}$ 。
表 - 1 対象地域における運河や都市施設の変遷

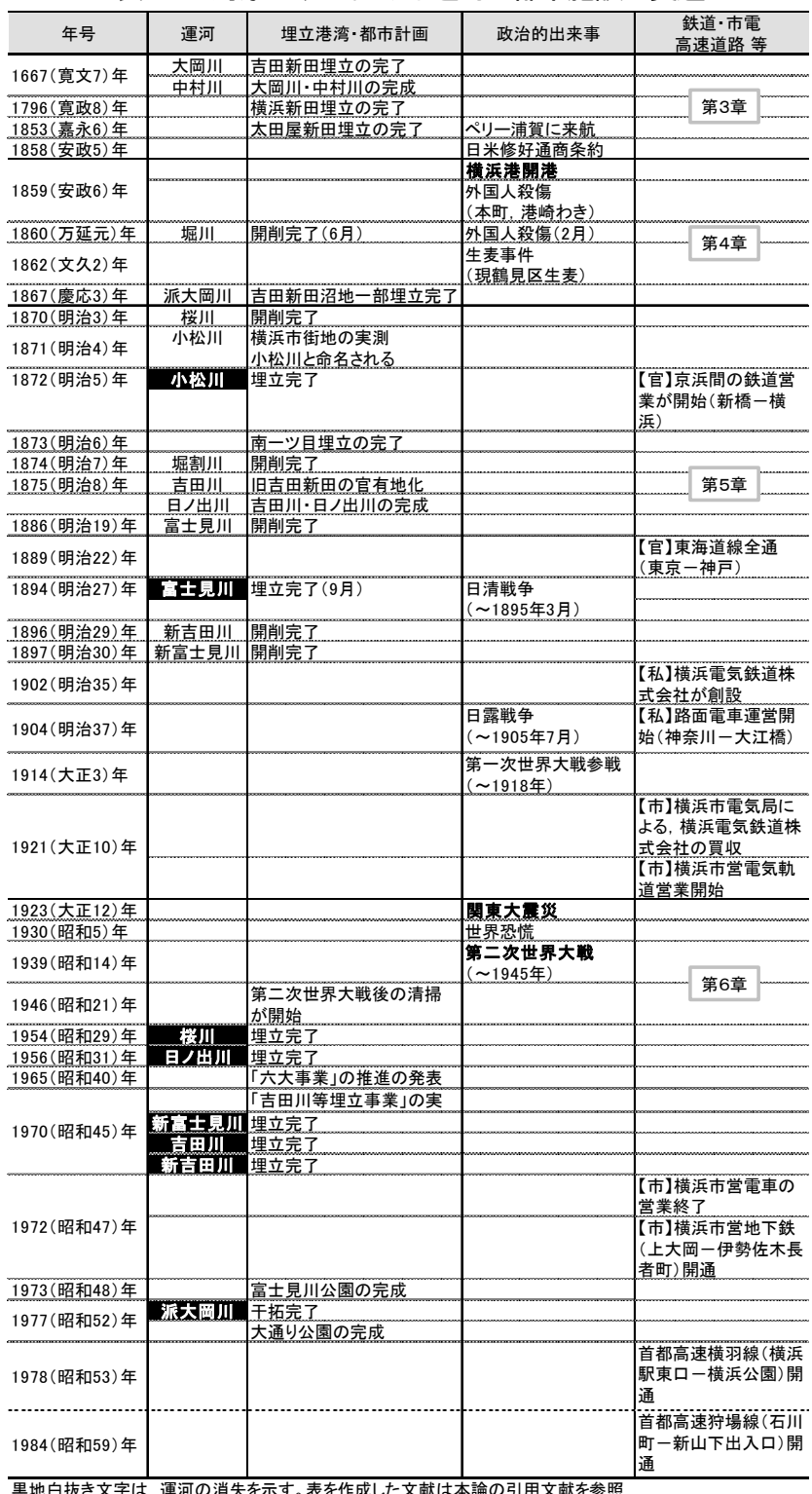

\section{（3）舟路としての運河の拡大}

市街地が拡大していた吉田新田であったが，西側の開削は殆ど 進行していなかった。そこで伏島近蔵は 1886 (明治 19) 年 1 月, この地域の舟運を通ずるために開削を出願した。しかしはじめは, 市制施行などの関係から実施されなかった。伏島は，沖田信亮と 両名共同し，1891（明治 24）年 12 月に再度出願し，「並行して 富士見川を埋め立て」「その代償として富士見川敷を下附」するこ とを条件とした ${ }^{47)}$ 。その結果，1893（明治 26）年 9 月に開削の 免許を得た。1894（明治 27）年 9 月 3 日の新吉田川開削工事起 工と同時に富士見川埋め立ては完成し，新吉田川の開削は 1896 （明治 29）年に，新富士見川の開削は1897（明治 30）年に完成 した 48 。

\section{（4）明治 30 年以降 電気軌道（路面電車）の発展}

明治時代初期の鉄道網敷設を契機に，陸上交通網の発達が顕著 となった。日清戦争（1894〜95 年）前後から, 横浜市内におけ る市内路面電気鉄道の計画は現れていた。しかし県会の反対や人 力車夫の電鉄敷設反対運動が起こり，実現には至らずにいた。そ の和解の末，1900 (明治 33) 年 9 月に敷設出願の許可が下り, 1902 (明治 35$)$ 年 7 月 23 日に横浜電気鉄道・横浜共同電気鉄道・ 鎌倉電気鉄道・横浜市内電気鉄道の四社が一本にまとまった結果, 


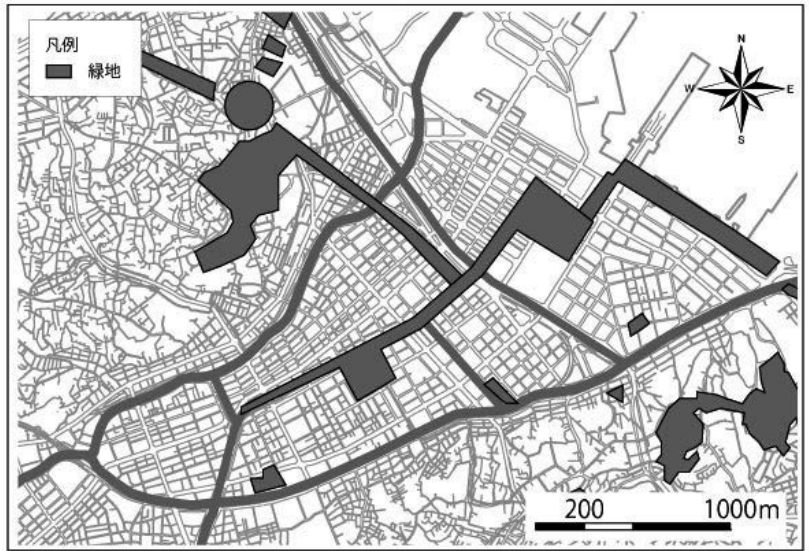

図 - 2 横浜復興計画案に示された緑地

横浜電気鉄道株式会社が創立された 49),50)。1904（明治 37）年, 神奈川・大江橋 (桜木町) 間において, 横浜で最初の路面電車 (電 気軌道）の営業が開始された。この区間は，本来別個の町であつ た横浜と神奈川を結ぶ都市間電車の色彩が当時としては強かった。 しかしその後は営業範囲を市街地に拡大し, 明治末期から大正初 期にかけて各方面一郊外路線を伸ばしていった ${ }^{51)}$ 。横浜電気鉄道 株式会社は，第一次世界大戦をめぐる物価高騰，それに起因した 生活擁護のための従業員待遇改善の要求，他方での電鉄交友論の 発生などから，1921（大正 10）年 4 月 1 日，横浜市電気局開庁 と同時に横浜市に買収され，横浜市営電気軌道（横浜市営電車） として営業を開始した ${ }^{52}$ 。 以上から, 横浜市営電気鉄道は, 戦前・ 前後を通じて, 横浜の陸上交通を支える存在として重要な役目を 果たしていたと考えられる53)。

\section{6. 関東大震災とその後の運河の変遷}

\section{(1) 震災復興計画}

1923 （大正 12）年, 神奈川県相模湾北西沖 $80 \mathrm{~km}$ を震源とし た，関東大震災が発生した。横浜市の被害世帯の比率は，ほぼ全 滅に近い $95.5 \%$ という高い数值を示した。被害を大きくしたのは 地震と同時に大火㷋が発生したためであった。その後, 横浜市は 内務省より都市計画局長として牧彦七を招き，その下で，横濱復 興計画案が立案された（図－2）54）その大筋としては，横浜市 人口を 30 年後約 30 万人と想定し, 横浜港湾設備の拡張や, 関内 地区と丘陵地（現在の戸部町，伊勢町）を中枢地として, 鉄道・ 道路・運河・公園等の系統を揃えるというものであった。1927 (昭 和 2) 年の計画案には, 「新吉田川习埋築シ」街路を作る計画も含 まれていた。(当時の計画案内において, 緑地として指定された地

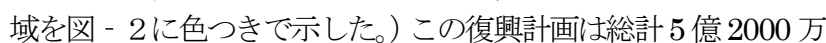
円という莫大な予算規模となったため実施されなかったが，横浜 市復興事業は主に土地区画整理事業，街路事業，公園事業で構成 されることとなり，現在につながる都市の骨格が作られることと なった ${ }^{55)}$ 。

\section{（2）終戦後の瓦碟処分と運河の埋立}

終戦後の市街地の清掃が行われたのは，1946（昭和 21）年 3 月中旬のことだった。鉄道やトラック輸送などの陸上交通機関が 整備される中, 日ノ出川の舟路としての利用価值が薄れていると の理由で桜川や日ノ出川は 1945 (昭和 22 ) 年 5 月の横浜大空襲 の残骸・瓦碩投棄処分場として指定された。そのため，現地付近 で処理しきれなかった瓦碟などが集積された。これが横浜市の戦 後の埋立のはしりになった 56)。桜川の埋め立ては1954（昭和 29） 年に，日ノ出川の埋め立ては 1956 (昭和 31 年）に完了した。

（3）自動車の普及と横浜市営電気軌道（横浜市営電車）の衰退 戦後の高度経済成長に呼応して，横浜市内における自動車保有 台数が増加したのは，昭和 40 年代のことであった。1965（昭和

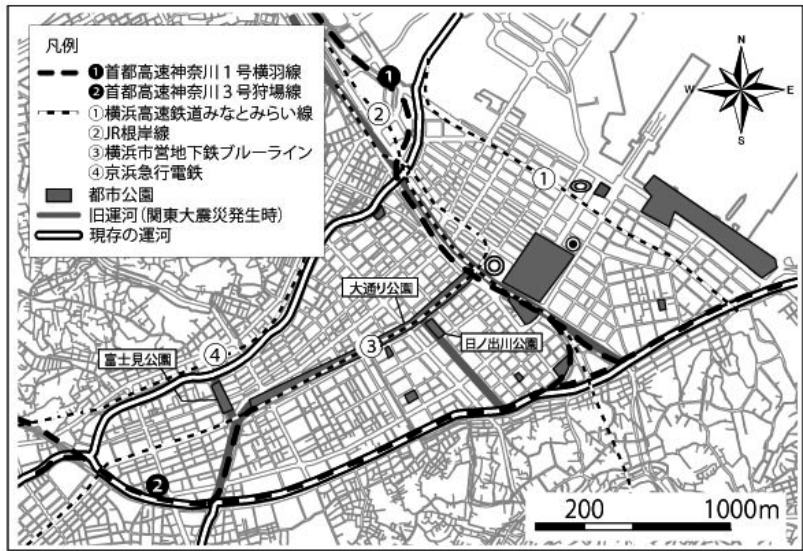

図 - 3 対象地域における現在の都市施設概要

40）年の横浜市内自動車保有台数は 113,076 台であったが, 1974 （昭和 49）年には 433,974 台と，ほぼ 4 倍にまで増加した。昭 和後期の交通の様子について,「近年の道路交通量は, 都心部では 道路容量をはるかに越えている。この原因の主なものは自動車の 増加で，(中略）これに伴って，バスの走行速度も次第に低下し， 交通機関としての役割に支障をきたしている。」と記載されている 57)。また, 横浜市営電気鉄道の一日平均乗車人数は 1929 (昭和 4) 年の 9,288 人を境に減少している。その後, 横浜市営電気鉄道は, 1972 (昭和 47$)$ 年 3 月 31 日に廃業した ${ }^{58)}$ 。

\section{(4) 高度経済成長と運河の消失}

横浜市を市民活動や娛楽等の都市活動の中心にするため，基盤 整備を行う必要があった。そこで，1965 年（昭和 40 年） 2 月に 「横浜の都市づくり将来計画の構想」が発表され，その具現化の ための「六大事業」の推進が発表された 56)。当時の報告書には, ほとんど利用されずに工場污染により悪臭を放つ運河は，景観上 も衛生上もマイナスの存在であるため, これら運河を埋め立て, 都市構成強化上，有效利用寸る事が望ましいといったといった内

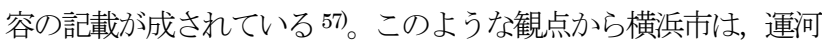
の埋立を行い，新しい都市施設の建設を進めることとした。昭和 45 年から計画された「大通り公園計画」は，『横浜市大通り公園 及び周辺地区開発基本構想』に基づいていた。全市的なスケール での「緑の軸線」を形成し，横浜の新しい顔となる，内陸都心開 発の手立てとして，都心に緑を回復，市民に䄭いの場を提供し， そして災害時の避難地にするなど，多目的使用の公園とするもの であった。さらに，公園の周辺地域の開発の手立てとすることな ども目的としていていた ${ }^{58)}$ 。 1970 年 (昭和 45 年) 3 月 27 日, 吉田川・新吉田川・新富士見川の埋め立てと, 派大岡川の干拓の 免許を市会全員協議会において得て，吉田川等埋立事業として実 施された 59)。このことは, 運河の機能停止というマイナス面だけ でなく, 新しい都市の施設を生多出すことになった ${ }^{60)}$ 。吉田川と 新吉田川が埋め立てられ，跡地には横浜市営地下鉄（上大岡・伊 勢崎長者町）が 1972 (昭和 47）年に開通し，その上には大通り 公園が 1978 （昭和 53）年に開園した。この公園の範囲は，震災 復興計画とほぼ同範囲であった。緑地計画が，約 50 年の時を経 て実現したと推察される。また, 1973 (昭和 48) 年, JR 根岸線 が桜木町から大船まで開通した。1978（昭和 53）年に，根岸線 の上に首都高速神奈川 1 号横习习線が横浜駅東口・横浜公園間で開 通した ${ }^{61)}$ 。さらに, 新富士見川が埋め立てられ，今まで悪臭を放 った運河が 1973 (昭和 48) 年 10 月に富士見川公園として再生し た ${ }^{56)}$ 。日ノ出川と吉田川の合流地点にあたる場所には, 日ノ出川 公園がある ${ }^{22)}$ 。さらに中村川・堀川上の高架に，1984（昭和 59） 年に首都高速神奈川 3 号狩場線が新山下出入口・石川町で開通し た61) (図 - 3) 63) 


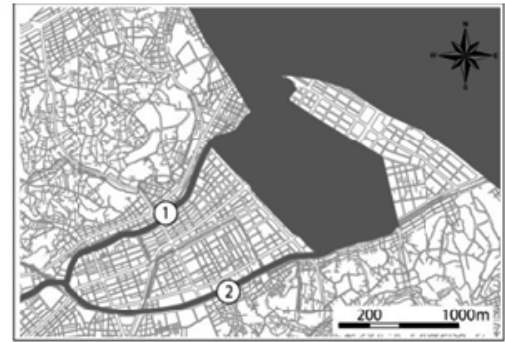

a.1851(霓永4) 年

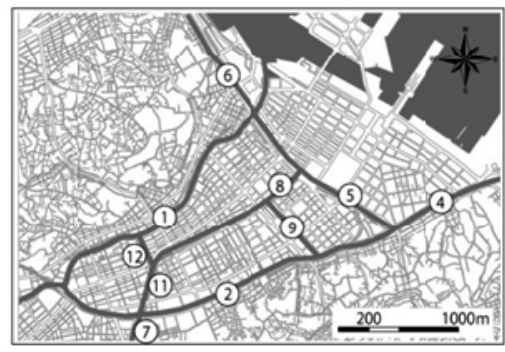

$\mathrm{d} 1897($ 明治 30$)$ 年

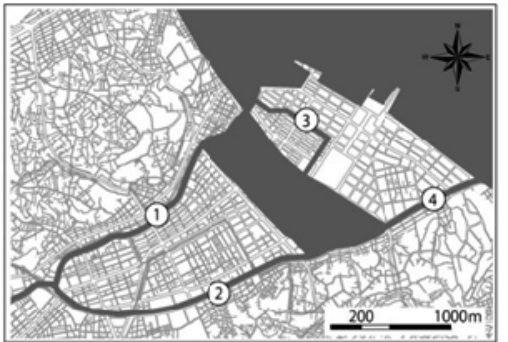

b1864(元治元) 年

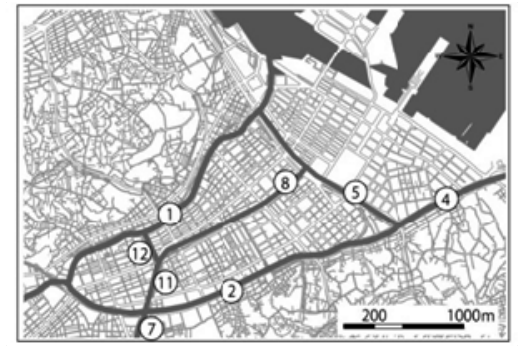

0.1966(昭和41) 年

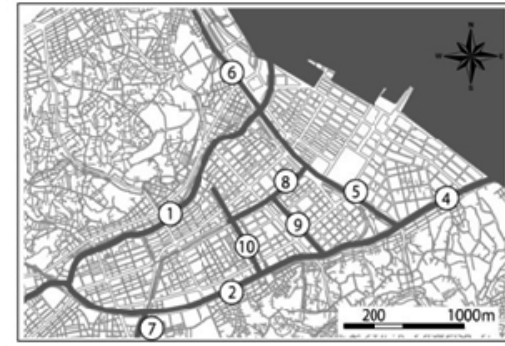

c.1890(明治23)年

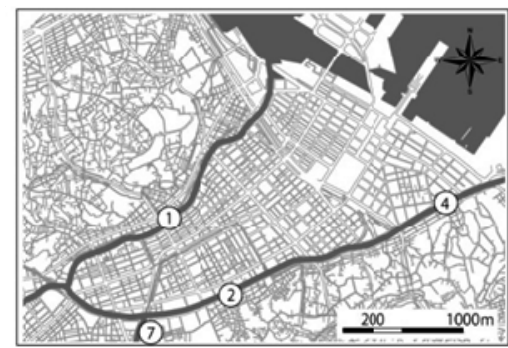

f.1976(昭和53)年

1:大岡川 2:中村川 3:小松川 4:堀川 5:派大岡川 6:桜川 7:堀割川 8:吉田川 9:日ノ出川 10:富士見川 11:新富士見川 12:新吉田川 横浜村並近傍之図 ${ }^{19} \cdot$ 横浜明細全図 ${ }^{16}$ - 改良横浜全図 ${ }^{17} \cdot$ 横浜市域図 ${ }^{18)}$ ，地図・空中写真 (国土地理院) ${ }^{19}$ をもとに作成した。 海岸線と運河はそれぞれの時代の資料から位置を記載した。陸地部分は，現在の街路を記載し，当時の運河の位置を確認できるようにした。

図 - 4 運河の開削と埋立の変遷

\section{7. 運河の発展と衰退から生まれた新しい都市施設}

約 350 年前の江戸時代から現在に至る運河の発展と衰退を図 4 と表 - 2 にまとめた。松と畑が見える程度であった横濱村の海 を土砂で埋め立て，115ha の吉田新田が 1667 （寛文 7）年に完 成した。この際，大岡川と中村川が誕生した。両運河は，現在も 残っている。図 - 4のa.の $2 つ の$ 運河のうち, 1 が大岡川であり, 2 が中村川である。その後，1867（慶応 3）年までに新たに埋め 立てられた吉田新田と, 横浜新田・太田屋新田との間に残された 運河が，派大岡川である。派大岡川は，1977（昭和 52）年に干 拓され，現在，跡地にはJR 根岸線が，上空には首都高速神奈川 1 号横习線が通っている。堀川は横浜港開港後に治安維持のため に開削された。堀川も現存し，上空には首都高速神奈川 3 号狩場 線が通っている。小松川は, 正確な開削時期は不明であるが, 1864

（元治元）年発行の古絵図より，その姿を確認できる。図 - 4の b.に新たに追加された 3 が小松川，4 が堀川，5 が派大岡川であ る。開港をきっかけとして市街地が拡大し，横濱村に大きな変化 が生じた。さらに物資輸送の増大から運河の必要性が高まった。 このことより，運河は舟路としての機能を果たし，利用されてい たと考えられる。桜川は，1870（明治 3) 年，市街地拡大のため の埋立の際に埋め残された運河であり，後に護岸が整備され，大 岡川と同様に，荷揚げの場としても栄えた。図－4のc.に新たに 追加された 6 が桜川である。しかし桜川は, 1954（昭和 29）年 に舟路としての機能低下を理由に, 戦災後の瓦碩投棄場に指定さ れ埋め立てられた。現在は自動車道となっている。堀割川は 1874 （明治 7）年に舟路として開削された運河である。図 - 4のc.に 新たに追加された 7 が堀割川である。堀割川は上流部で中村川と 結ばれ, 横浜港と周辺の地域を結ぶ重要な水上交通路としての役 割を果たした。堀割川は現在も存在し，河岸には艀船の姿が多数 見られる。吉田川と日ノ出川は1875（明治8）年に開削された堀 割川の土砂を用いた市街地埋め立ての際に埋め残された運河であ る。図-4のc.に新たに追加された 8 が吉田川であり，9 が日ノ 出川である。しかし，日ノ出川も桜川と同じ理由から，1956 (昭 和 31）年に, 戦災後の瓦碩投棄場として埋め立てられた。また, 吉田川は高度経済成長期に，舟路としての機能低下や衛生面での
マイナス面を指摘され，六大事業の一環として，1970（昭和 45） 年に埋め立てられた。現在は, 吉田川と日ノ出川の交差点は日ノ 出川公園となっている。富士見川は, 舟路として 1886 (明治 19) 年に開削された。図－4のc.に新たに追加された 10 が，富士見 川である。しかし，富士見川は，1896（明治 29）年の新吉田川 開削と 1897 (明治 30）年の新富士見川開削と並行して埋め立て られた。新吉田川と新富士見川が開削された理由もこれまでと同 様，舟運を通ずるためであった。図－4のd.に新たに追加された 11 が新富士見川，12 が新吉田川である。新吉田川と新富士見川 も吉田川と同様の理由により, 1970 (昭和 45）年に埋め立てら れた。現在は，吉田川と新吉田川の跡地は横浜市営地下鉄伊勢崎 線となっており，地上部は緑豊かな大通り公園となっている。新 富士見川跡地は現在，富士見川公園となっている。

以上から, 運河の埋め立てが盛んに行われた時期は, 昭和初期 から昭和後期にかけてであったことがわかる。開削が盛んに行わ れていた当初は, 運河は主に舟路としての機能を果たし, 利用さ れていた。しかし, 明治後期の路面電車運営開始後, 横浜市内の 舟路としての役割に陰りが見え始める。1923（大正 12）年に発 生した関東大震災による被害を受けて計画された横濱復興計画案 に, 「新吉田川习埋築シ」街路を作る計画が組まれていた。また, 終戦後の市街地の清掃の際,「横浜大空襲の残骸・瓦碩の投亲処分 場として指定された」ことより, 横浜の運河機能はこの頃にはほ ぼ停止していたと推測できる。さらに，鉄道やトラック輸送など の陸上交通の発達とともに運河の「舟路としての利用価值が薄れ ている」といら理由から, 運河の埋立が続いた。さらに, 高度経 済成長期に工場から排出された污水や污物等で著しく污染された 運河は, 都市景観や衛生面から完全に疎まれる存在となった。そ の結果, 新たな都心開発のため, 運河を埋め立て, その地に新た な都市施設の創造が行われることとなったのである。

\section{8. おわりに}

本研究は,「運河の発展と衰退の経緯」と「現在の都市施設の創 造」との関係性を明らかにした。調査の結果, 運河の発展の経緯 に関して，対象地運河には舟運機能のみならず，外国人居留地の 
表 - 2 対象地域における運河の発展と衰退の理由まとめ

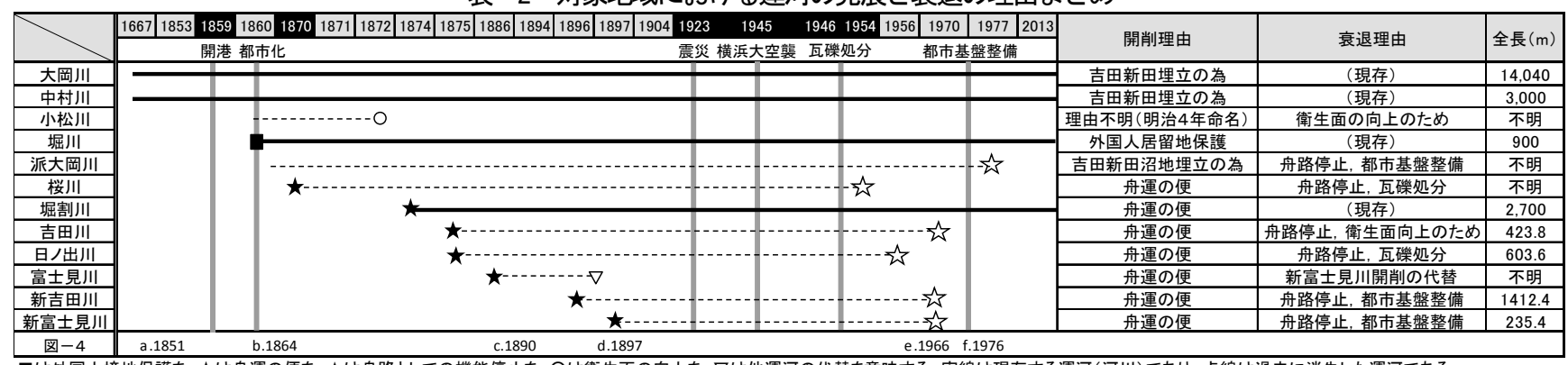

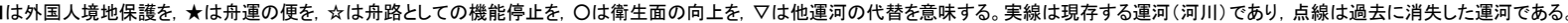

表は, 本文の引用文献より作成した。運河の全長は大岡川・中村川·堀川·掘割川は, 現在の延長を横浜市道路局河川計画課資料より引用した。その他河川は, 横濱旧吉田新田の研究107項による。

「図-4」の行は, 本文中の図-4に示した運河の地図年代を示している。

防犯柵としての機能が求められていた事が明らかとなった。この ことより, 対象地における運河の発展には「横浜港開港」という, 他の都市部とは異なった特徴的な歴史背景が認められる。また， 運河の衰退の経緯に関して, 都市化に呼忘した陸上交通網の発達 により，徐々に舟路としての機能が薄れていた上に，関東大震桨 や横浜大空襲が決定打となり，運河の埋立や暗渠化が立て続けに 実行されたということが明らかとなった。その後の都市基盤整備 の結果，運河が埋め立てられた跡地は，都市公園や緑道，地下鉄 へと変わっている。また，暗渠化された地域では，運河上空に高 速道路が架けられるなど，様々な新しい都市施設の存在を確認で きる。

以上より，対象地域において運河は，長い歴史の中で生活と共 に変化を続けていることから，文化的な価值を持ち，地域個性と 呼ぶに相応しいといえる。したがって運河は，各時代の風景を特 徵づける存在として大きな役割を果たしていたと結論付けること ができる。

謝辞 : 本研究はJSPS 科研費 24658023 の助成を受けました。

\section{補注及び引用文献}

1）白藤裕 奥田宗幸 中畑昌之 日向恭兵 山田択麿（2009）：地下化された河川の痕跡 から都市の風景を読夕解く：日本建築学会学術講演梗概集 F-2, 建築歴史・意匠 2009, $755-756$

2) 高橋信之 尾島俊雄 (1986) : 東京 23 区における廃止河川の利用形態に関寸る研究 : 日本建築学会計画系論文報告集(364), 134-142

3）小川拓馬 (2011) : 暗渠加ら解読寸る東京の原風景 : 日本建築学会大会学術講演梗 概集 F-2, 建築歴史・意匠 $2011,597-598$

4) 岡真由美 中津秀之 (2008) : 横浜市大岡川流域における都市形成の変遷に関寸る 研究: 日本建築学会学術講演梗概集 F-1, 都市計画, 建築経済・住宅問題 2008, 109-110

5) 吉田峰弘 陣内秀信 (2008) : 新橋と横浜の比較 : 交通の変遷が都市空間の展開に与 えた影響 : 日本建築学会学術講演梗概集 F-2, 建築歴史・意匠 $2008,335-336$

6）国土交通省国土政策局が公開している国土数值情報ダウンロードサービスから国土 骨格のベクトルデータを 2013 年 8 月にダウンロードしArcGIS を用いて現在の地 図を作成したここの地図上に, 横浜村並近傍之図 7) ・ 横浜明細全図 ${ }^{8)} \cdot$ 改良横浜全 図 9 ・ 横浜市域図 10 より得た情報を重ねて図一 1 を作成した。図中の黑は現在の海 である。

7) 千葉大学附属図書館松戸分館所蔵小寺文庫藏書「横濱村並近傍之図 (1851)」。「横 濱村並近傍之図」は鈴木重治が描いた俯瞰図に渡辺修一郎が注釈を加えたものであ るという説明が残されている。

8）千葉大学附属図書館松戸分館所蔵小寺文庫蔵書「横濱明細全図 (1864)」。筆者は一 川芳員と記されている。

9) 横浜市立図書館所蔵「改良横浜全図 (1890)

10) 千葉県立西武図書館所蔵「横浜市域図 (1897)」

11）横浜市道路局河川計画課 : 横浜市河川の概要 : 横浜市ホームページ $<$ http://www.city.yokohama.lg.jp/doro/kasenkeikaku/menu/gaiyou/>2012.04.01 更新,2013.9.17 参照

12）横浜市政策局総務部統言十情報課 : 人口ニュース : 横浜市ホームページ $<$ http://www.city.yokohama.lg.jp/ex/stat/jinko/news-j.html>2013.7.1 更新,2013.7.20 参照

13）横浜市港南区 : 港南区の位置，地勢 : 横浜市ホームページ <http://www.city.yokohama.lg.jp/konan/furusato/outlnmin.html>2012.11.1 更新, 2013.7.20 参照

14）横浜市建築局 : 横浜市土地利用のあらまし : 横浜市ホームページ $<$ http://www.city.yokohama.lg.jp/kenchiku/kikaku/cityplan/kisocho/ > 2013.5. 1 更新, 2013.7.20 参照

15）図一4のa.は，7)を用いて作成した。

16）b.は8)を用いて作成した。

17）c.は9)を用いて作成した。

18）d.は10)を用いて作成した

19）e.及びf.は，地図・空中写真（国土地理院公開データ）をもとに作成した。

20）石野瑛（1973）: 横濱舊吉田新田の研究 : 名著出版，46

21）前掲 20)， 153

22) 1 坪 $=0.000330579 \mathrm{ha}$ ，江戸時代平均金 1 両二約 6.6 万円で計算。

23）横浜市 (1932) : 横浜市史稿地理編 : 横浜市，605

24）前掲 15), $50-51$

25）前掲 20), 19

26）前掲 20), 31

27) 前掲 20), $96-99$

28）前掲 20), 34

29）前掲 20)， 100

30) 1 間 $=1.818 \mathrm{~m}$ として計算。

31）横浜市中区 (1985)：中区史 : 横浜市中区役所，198

32）前掲 23)， 635

33）前掲 31)， 207

34）前掲 31)， 209

35) 大野太衛 (1908) : 高島翁言行録 188-189

36）堀割川の会 (2011) : 磯子の水辺から一堀割川その復権一: ア术听师价， 31

37）前掲 20), 113-117

38）前掲 23)， 648

39）前掲 23), 649

40）前掲 31)，507-508

41）横浜開港資料館: 伏島近蔵が築いた新吉田川と新富士見川: 横浜開港資料館ホーム ページ< http://www.kaikou.city.yokohama.jp/journal/095/02-2.html >

2007.1.31 更新，2013.9.20 参照

42) 横濱市役所 (1932)：横濱復興誌， 767

43) 前掲 42), 766

44) 横浜市 (1965) : 横浜市史四巻上 : 横浜市, 618

45）前掲 44), 620

46) 前掲 44), 632

47) 前掲 23), 623-624

48）前掲 41)

49）横浜市交通局（1972）: ちんちん電車・八マッ子の足七○年 : 横浜市交通局, 24

50）前掲 44), 672

51）岡田直（2011）：「地図」で探る横浜の鉄道 : 横浜都市発展記念館, 34

52 ) 横浜市 (1927) 発行, 『横浜市復興会誌』付図より作成。牧彦七による横浜の復興 計画案。直線的に配置されたグリーンベルト (緑地帯) が画期的であった。山下 町地先の緑地はその後, 震桨の瓦碩を埋め立てられ, 山下公園となる。

53）横浜市 (1981) : 港町・横浜の都市形成史 : 横浜市企画調整局, 67

54）横浜市 (1992) : 横浜の埋め立て : 横浜市港湾局臨海開発部, 80

55) 横浜市 (1975) : 横浜市の高速鉄道計画 : 横浜市交通局

56) 横浜市 (1976) : 横浜市史五巻中 : 横浜市, 161

57) 横浜市政策局: 調查季報 28 号 特集 六大事業の経過と今後の方向: 横浜市ホー ムページ，94-95<http://www.city.yokohama.lg.jp/seisaku/seisaku/chousa/ kihou/28/>2012.11.29 更新, 2013.9.20 参照

58）前掲 31），454

59）前掲 57), 84

60）前掲 31)，451

61）高速道路資料室 : 首都高速道路(4) $\mathrm{K} 1 \cdot \mathrm{K} 2 \cdot \mathrm{K} 3 \cdot \mathrm{K} 5 \cdot \mathrm{K} 6 \cdot \mathrm{S} 1 \cdot \mathrm{S} 2 \cdot \mathrm{S} 5$ : <http:// www.ne.jp/asahi/expressway/dataroom/ $>2013.9 .15$ 更新, 2013.9 .19 参照

62）前掲 31), 464

63）国十交通省国十政策局が公開している国十数值情報ダウンロードサービスから国 土骨格のベクトルデータを 2013 年 8 月にダウンロードし, ArcGIS を用いて作成 した。 